\title{
Telmisartan Improves Memory Impairment in a Mouse Model of Type 2 Diabetes
}

\author{
Tao DG ${ }^{1}$, Dong $\mathrm{RR}^{2}$, Wang $\mathrm{C}^{2}$, Guang $\mathrm{JL}^{1^{*}}$, Tang $\mathrm{SS}^{2}$, Hu $\mathrm{M}^{2}$, Long $\mathrm{Y}^{2}$ and Hong $\mathrm{H}^{2^{*}}$ \\ ${ }^{1}$ Department of Pharmacy, Changzhou No. 2 People's Hospital Affiliated with Nanjing Medical University, Changzhou 213003, China \\ ${ }^{2}$ Department of Pharmacology, China Pharmaceutical University, Nanjing 210009, China
}

*Corresponding authors: Guang Jun Liu, Department of Pharmacy, Changzhou No. 2 People's Hospital, Changzhou 213003, China, Tel: +86-519-81087628; E-mail: liuguangjun@medmail.com.cn

Hao Hong, Department of Pharmacology, China Pharmaceutical University, Tong Jiaxiang, Nanjing, China, Tel: +86-25-86185227; E-mail: honghao@cpu.edu.cn Received date: December 5 th, 2015 ; Accepted date: March $7^{\text {th }}, 2016$; Published date: March $14^{\text {th }}, 2016$

Copyright: @ 2016 Tao DG, et al. This is an open-access article distributed under the terms of the Creative Commons Attribution License, which permits unrestricted use, distribution, and reproduction in any medium, provided the original author and source are credited.

\begin{abstract}
Telmisartan, an angiotensin II type 1-receptor blocker (ARB), has been reported to exert beneficial effects on the central nervous system (CNS) in streptozotocin (STZ) - induced diabetic mice. However, the effect of telmisartan on cognitive impairment associated with type 2 diabetes is not well known. Here, we investigated the effects of telmisartan on memory impairment in a mouse model with defects in insulin sensitivity and secretion, namely highfat diet (HFD) /STZ-induced diabetic mice. Our data showed that STZ / HFD diabetic mice, characterized by hyperglycemia and hypoinsulinemia, performed poorly on Morris water maze (MWM) test. Such learning and memory impairment was accompanied by increased $\beta$-amyloid peptide 42 (A 342 ), amyloid precursor protein (APP), $\beta$-site amyloid precursor protein cleaving enzyme (BACE1), the receptor for advanced glycation end products (RAGE) and nuclear factor $-\mathrm{KB}(\mathrm{NF}-\mathrm{KB})$ signaling in brain. Treatment with telmisartan significantly improved learning and memory in the diabetic mice and decreased A 42 , APP, BACE1 RAGE and NF-KB signaling in the brain without affecting hyperglycemia and hypoinsulinemia. It is concluded that telmisartan may be considered as a potential pharmacological agent for the management of cognitive dysfunction in type 2 diabetes.
\end{abstract}

Keywords: Telmisartan; Type 2 diabetes; Memory; Amyloidosis

\section{Introduction}

Type 2 diabetes (T2D) is a complex, age-related chronic disease with an increasing prevalence of health concern. T2D causes accelerated aging in most organ systems leading to premature morbidity and mortality [1]. For example, major T2D-related complications include kidney damage, neuropathy, blindness and coronary artery disease. It has been confirmed that T2D has negative impacts on the central nervous system leading to diabetic encephalopathy and concomitant augmentation of cognitive impairments [2,3]. A growing body of evidence links T2D with dementia and neurodegenerative diseases such as Alzheimer's disease (AD) and one in ten cases of dementia in the world population may be attributable to the effects of T2D $[4,5]$.

Telmisartan, an angiotensin II type receptor 1 (AT1R) blocker (ARB), is widely used in patients with hypertension with the expectation of a decrease in the onset of cardiovascular and cerebrovascular disease. Recently, the focus on ARBs has been intensified because their novel biological roles have emerged, particularly for their therapeutic potential in the brain disorders [6,7]. It has been reported that telmisartan exerts a protective effect in a murine model of ischemia / reperfusion injury through blockade of AT1R and exhibits anti-apoptotic, anti-inflammatory, and anti-oxidant benefits in the intracerebral hemorrhage rat model [8-11]. Recent studies showed that telmisartan protects mouse dopaminergic neurons and inhibits the microglial response in a mouse MPTP model of Parkinson's disease $[12,13]$. Furthermore, treatment with telmisartan significantly attenuated hypertension-induced learning and memory deficits, endothelial dysfunction, accumulation of cellular amyloid $\beta$, and changes in various biochemical parameters [14,15]. In some experimental animal models of $\mathrm{AD}$, telmisartan exhibited significant ameliorative effects on the impaired spatial memory and inflammatory response [16-19]. Clinical investigation demonstrated that telmisartan improves cognitive function in patients with metabolic syndrome and elderly hypertensive patients with $\mathrm{AD}$, type 3 diabetes $[20,21]$. Our previous studies showed that telmisartan at nonhypotensive dose reverses memory impairment in streptozotocin (STZ) - induced diabetic mice [22]. To date, less attention has been given to the effect of telmisartan on the cognitive impairment in T2D. High-fat diet (HFD) / STZ-induced diabetic mice, model is similar to human type 2 diabetes in clinical symptoms, including more drinks, polyphagia, polyuria, obesity, hyperglycemia, insulin resistance and lipid metabolic disorder syndrome. This study was undertaken to investigate the effects of telmisartan on memory impairment and $\mathrm{A} \beta 42$, APP, BACE1 RAGE and NF- $\kappa \mathrm{B}$ signaling in the mouse brain of HFD / STZ-induced diabetic mice, which is associated with impaired hippocampus-dependent learning and memory.

\section{Materials and Methods}

\section{Materials}

Telmisartan(4'-[(1,4'-Dimethyl-2'-propyl[2,6'-bi-1H-

benzimidazol]-1'-yl)methyl][1,1'-biphenyl]-2-carboxylic acid) was purchased from hunan dinuo pharmaceutical Co., Ltd. (Liuyang, China. Lot: 140432). High-fat diet (HFD, food composition: 20\% lard, 9.5\% sugar, $10 \%$ yolk power, $1.5 \%$ salt, $59 \%$ conventional food; calorie composition: $60 \%$ fat, $20 \%$ protein and 20\% carbohydrate) was purchased from Jiangsu Province Cooperative Medicine Biological Engineering Co., Ltd. (Nanjing, China). STZ was purchased from 
Sigma-Aldrich (USA. Lot: 100712062). Rabbit anti-mouse A $\beta 42$ and receptor for advanced glycation end products (RAGE) were purchased from Abcam Technology Co., Ltd. (Hongkong, China). And rabbit anti-mouse $\beta$-amyloid precursor protein (APP), $\beta$-site APP cleaving enzyme 1 (BACE1) and NF- $\kappa$ B p65 from Cell Signaling Technology (Boston, MA, USA). Rabbit anti-mouse $\beta$-actin and histone H3, goat anti-rabbit secondary antibodies were obtained from Bioworld Technology Co., Ltd. (Minneapolis, MN, USA). Strept avidin-biotin complex (SABC) immunohistochemistry kit was purchased from Boster Biotechnology Co., Ltd (Wuhan, China). Glucose Oxidase Kit and insulin Sandwich ELISA kit were purchased from Nanjing Jiancheng Biotech Institute (Nanjing, China), and all other chemicals were of analytical grade and commercially available.

\section{Animals}

Approximately 3 months old ICR male mice (weighing $20 \mathrm{~g}-25 \mathrm{~g}$ ) was provided by Medical Center of Yangzhou University (Yangzhou, China). The animal experimental protocol and procedures are compliance with the guidelines of the Institutional Animal Care and Use committee of China. Seven mice were housed per cage with food and water available at a constant room temperature $25^{\circ} \mathrm{C}$ and maintained on a $12 \mathrm{~h}$ light / $12 \mathrm{~h}$ dark cycle (lights on at 07:00 AM).

\section{Experimental induction of T2D and telmisartan treatment}

All mice were habituated to the cage for 5 days before the experiments. The animals were housed with HFD for 4 weeks and then injected with low dose of STZ (100 mg/kg, intravenously) dissolving in citrate buffer $(\mathrm{pH} 4.5)$ to induce the function deficit of pancreas, followed by continued HFD feeding for 4 weeks. After 8 weeks, mice were screened for fasting blood glucose levels, and animal having fasting serum glucose $\geq 11.1 \mathrm{mmol} / \mathrm{L}$ were considered diabetic mice [23-25]. According to hyperglycemia and body weight, diabetic animals were randomly divided into 3 groups, vehicle group (STZ / HFD + Veh), 0.35 mg/kg telmisartan group (STZ / HFD + Tel 0.35 mg/ $\mathrm{kg}), 0.70 \mathrm{mg} / \mathrm{kg}$ telmisartan group (STZ / HFD + Tel $0.70 \mathrm{mg} / \mathrm{kg}$ ). Age-matched control mice were treated with the vehicle. Telmisartan was dissolved in $0.5 \%$ sodium carboxymethyl cellulose (CMC-Na). The duration for oral administration was 5 weeks and body weight was monitored every 2 days. After 5 weeks of telmisartan treatment, the surviving animals were used for the Morris water maze (MWM) task to evaluate memory function. After the MWM test, blood glucose and serum insulin were determined using assay kits. All animals were sacrificed by cervical dislocation and brain tissues were taken out for the assays of A $\beta 42$, APP, BACE1 RAGE and NF- $\mathrm{B}$ p65 in the hippocampus and cortex.

\section{Morris water maze task}

Cognitive function was assessed by the MWM test, which consisted of 5 day training (visible and invisible platform training sessions) and a probe trial on day 6 . This was carried out as described previously. Mice were individually trained in a circular pool $(120 \mathrm{~cm}$ diameter, $50 \mathrm{~cm}$ height) filled up to a depth of $30 \mathrm{~cm}$ with water maintained at $25^{\circ} \mathrm{C}$. The maze was located in a lit room with visual cues. A platform $(9 \mathrm{~cm}$ diameter) was placed in the center of one quadrant of the pool. The platform's position was unchanged throughout the visible and hiddenplatform training sessions; the starting points were pseudorandomized for each trial, with the animals facing toward the wall. Each mouse was individually trained in both visible-platform (days 12) and hidden-platform (days 3-5) versions. Visible-platform training was performed for baseline differences in vision and motivation; the platform was placed $1 \mathrm{~cm}$ underneath the surface of the water and was indicated by a small flag $(5 \mathrm{~cm}$ in height). The hidden-platform version evaluates spatial learning and was used to determine the retention of memory to find the platform. During the training, the platform without the flag was placed $1 \mathrm{~cm}$ underneath the surface of the water. On each day, the animals were subjected to four trials with a $1 \mathrm{~h}$ interval between trials. Each trial lasted for $90 \mathrm{~s}$ unless the animal reached the platform first. If an animal failed to find the platform within $90 \mathrm{~s}$, the test was ended and the animal was gently navigated to the platform by hand for $30 \mathrm{~s}$. On day 6 , the platform was removed and the probe trial was started, during which animals had $90 \mathrm{~s}$ to search for the platform. The time spent in the target quadrant and the number of target crossings (i.e., the quadrant where the platform was previously located) was recorded. Data of the escape latency, the time spent in the target quadrant was collected by the video tracking equipment and processed by a computer equipped with analysis-management system (Viewer 2 Tracking Software, Ji Liang Instruments, China).

\section{Western blot analysis}

Hippocampus and cortex of mice were chopped into small pieces and then homogenized in $0.5 \mathrm{~mL}$ of RIPA buffer. The dissolved protein was collected from the supernatant after centrifugation at 12,000 $\mathrm{g}$ for $15 \mathrm{~min}$. The protein concentrations were measured using Coomassie blue-based assay reagent and then protein expression of A $\beta 42$, APP, BACE1, RAGE, and NF- $\mathrm{kBp} 65$ were assessed. Protein extracts were separated by a SDS-polyacrylamide gel electrophoresis and then transferred onto a PVDF membrane. The membrane was blocked with $5 \%$ skim milk in Tris buffer saline and then incubated at $4^{\circ} \mathrm{C}$ overnight with the respective primary antibodies for rabbit anti-A $\beta 42$ (1:500), APP (1:500), BACE1 (1:500), RAGE (1:500) and $\beta$-actin (inner control, 1:500). After washing with TBST, the membranes were incubated with a horseradish peroxidase-conjugated secondary antibody (1:2000) for $2 \mathrm{~h}$ at room temperature. The antibody-reactive bands were visualized by using the enhanced chemiluminescence detection reagents by a gel imaging system (Tanon Science and Technology Co., Ltd., Shanghai, China).

Nuclear extracts were prepared using nucleoprotein extraction kit (Sangon Biotech, China). Briefly, mouse hippocampus or prefrontal cortex were homogenized in ice-cold hypotonic buffer containing $0.5 \%$ phosphatase inhibitor, $1 \%$ phenylmethylsulfonyl fluoride and $0.1 \%$ DLdithiothreitol, then centrifuged at $4^{\circ} \mathrm{C}, 3000 \mathrm{~g}$ for $5 \mathrm{~min}$. The precipitate was washed with hypotonic buffer and centrifuged at $4^{\circ} \mathrm{C}$, $5000 \mathrm{~g}$ for $5 \mathrm{~min}$. Finally, $0.2 \mathrm{ml}$ lysis buffer containing $0.5 \%$ phosphatase inhibitor, $1 \%$ phenylmethylsulfonyl fluoride and $0.1 \%$ DLdithiothreitol were add into the precipitate, chilled for $20 \mathrm{~min}$ and centrifuged at $4^{\circ} \mathrm{C}, 15000 \mathrm{~g}$ for $10 \mathrm{~min}$. The supernatant nuclear protein extract was subjected to Western blot for assays of NF- $\mathrm{B}$ p65 (1:500) and histone H3 (1:500) was used as a loading control.

\section{Immunohistochemistry detection}

Immunohistochemical staining was performed using the strept avidin-biotin complex (SABC) immunohistochemistry kit according to the manufacturer's instructions (Boster Biotechnology Co., Ltd). Briefly, anesthetized mice were transcardially perfused with $0.1 \mathrm{~mol} / \mathrm{L}$ PBS containing $5 \mathrm{U} / \mathrm{ml}$ heparin and brains were fixed in $4 \%$ paraformaldehyde for $18 \mathrm{~h}$, followed by $30 \%$ sucrose for $24 \mathrm{~h}$. Brains were dissected and embedded into optimal cutting temperature (OCT) compound (Tissue-Tek, Torrance, CA) on dry ice. OCT-embedded 
fresh frozen brain tissue sections were cryosectioned at a thickness of $18 \mu \mathrm{m}$ and subsequently mounted on glass slides. After washed with $0.1 \mathrm{M}$ PBS, the sections were treated with $3 \% \mathrm{H}_{2} \mathrm{O}_{2}$ at room temperature for $10 \mathrm{~min}$ and washed for $3 \mathrm{~min} \times 5 \mathrm{~min}$. Sections were blocked with $0.3 \%$ Triton X-100 and 5\% BSA for $1 \mathrm{~h}$ and then incubated in anti-A $\beta 42(1: 100)$ primary antibody diluted in blocking solution overnight at $4^{\circ} \mathrm{C}$. Sections were washed in PBS $(3 \mathrm{~min} \times 5$ $\left.\min , 37^{\circ} \mathrm{C}\right)$, incubated with biotinylated mouse anti-rabbit IgG at $37^{\circ} \mathrm{C}$ for $20 \mathrm{~min}$, washed in $\mathrm{PBS}\left(3 \mathrm{~min} \times 5 \mathrm{~min}, 37^{\circ} \mathrm{C}\right)$, and incubated with strept avidin-biotin complex at $37^{\circ} \mathrm{C}$ for $20 \mathrm{~min}$. After a further $4 \mathrm{~min}$ $\times 5$ min washes in $0.1 \mathrm{M} \mathrm{PBS}$, diaminobenzidine (DAB) was used as the final chromogen at $37^{\circ} \mathrm{C}$ for detection of target proteins. After gradient dehydration ( $70 \%$ ethanol $5 \mathrm{~min}, 95 \%$ ethanol $5 \mathrm{~min}, 100 \%$ ethanol $2 \mathrm{~min} \times 5 \mathrm{~min}, 100 \%$ xylene $2 \mathrm{~min} \times 5 \mathrm{~min}$ ), photomicrographs were obtained using a Nikon DS-Fi2 camera connected to a Nikon Eclipse Timicroscope.

\section{Blood glucose and serum insulin assays}

After an overnight fast, bloods sample were collected from animal venae angularis and left room temperature for $10 \mathrm{~min}$, then centrifuged at $3000 \mathrm{~g}$ for $15 \mathrm{~min}$ and separated serum from the blood cells. Serum glucose was determined by enzymatic glucose oxidase peroxidase diagnostic kit. Serum insulin levels were measured by Sandwich ELISA kit.

\section{Statistical analysis}

Data are expressed as mean \pm SEM. In particular, group differences of escape latencies in the MWM were analyzed using by two-way ANOVA. The other data were analyzed by a one-way ANOVA followed by a Dunnett's post-hoc analysis for multiple comparisons. All analysis was carried out using SPSS, version 20.0. Statistical significance was considered when $\mathrm{P}<0.05$.

\section{Results}

\section{Telmisartan improves memory deficits in STZ / HFD- induced diabetic mice}

We first performed MWM text to assess the spatial memory performance of the STZ / HFD-induced diabetic mice. Each group showed similar escape latency in the visible-platform test, and statistical analysis revealed no significant difference in vision or basal motivation among all groups $(\mathrm{F}(3,265)=3.129, \mathrm{P}>0.05$, Figure $1 \mathrm{~A})$.

We then tested the mice in the 3 day spatial hidden-platform variant, and results suggested that diabetic mice untreated with telmisartan exhibited significant extension in escape latencies compared to those of control mice $(\mathrm{F}(3,379)=5.829, \mathrm{P}<0.05$, Figure 1B). Telmisartan at $0.35 \mathrm{mg} / \mathrm{kg}$ or $0.70 \mathrm{mg} / \mathrm{kg}$ markedly reversed the increase in escape latencies in the diabetic mice $(\mathrm{P}<0.05)$. We performed the probe trial ( 1 trial/mouse), a putative measurement of spatial learning and memory retention, all the mice showed preference for the target quadrant, with the exception of untreated diabetic mice which displayed significant decrease $(20.5 \%)$ in the percentage of total time in the target quadrant $(\mathrm{F}(3,37)=4.018, \mathrm{P}<0.05$, Figure $1 \mathrm{C})$. Representative swim paths were shown in Figure 1D. Diabetic mice treated with telmisartan $0.35 \mathrm{mg} / \mathrm{kg}$ or $0.70 \mathrm{mg} / \mathrm{kg}$ significantly increase to 3 and 3.2 in the number of crossing the platform, respectively, compared with diabetic mice treated with vehicle $(\mathrm{F}(3,37)$ $=4.242, \mathrm{P}<0.05$, Figure $1 \mathrm{E})$. The average swimming speed of locomotive parameter exhibited no difference among groups (Figure 1F). These data indicated that telmisartan improved learning and memory deficits in the diabetic mice.

\section{Telmisartan treatment decreases $A \beta 42$ in the brain of the diabetic mice}

Accumulating evidence suggests that $A \beta$ accumulation in the brainin diabetic condition may be one of the reasons for diabetesassociated impairment of cognition [26,27]. Therefore, we determined A $\beta 42$ peptide, a potential neurotoxic form of the peptide, using Western blot. Compared with control group, the STZ / HFD-induced diabetic mice showed $156 \%$ and $149 \%$ increase in A $\beta 42$ level of both hippocampus and cerebral cortex, repsectively, whereas the diabetic mice treated with telmisartan at $0.35 \mathrm{mg} / \mathrm{kg}$ or $0.7 \mathrm{mg} / \mathrm{kg}$ markedly inhibited $\mathrm{A} \beta 42$ production in hippocampus $(\mathrm{F}(3,15)=13.771, \mathrm{P}<$ 0.05 , Figures $2 \mathrm{~A}$ and $2 \mathrm{~B})$ and cortex $(\mathrm{F}(3,15)=9.844, \mathrm{P}<0.05$, Figures $2 \mathrm{~A}$ and $2 \mathrm{~B}$ ) relative to those of untreated diabetic mice. To further confirm our results, we performed immunohistochemical staining experiment using immunohistochemistry kit. This result bolstered the data from the Western blot, and the immunoreactivity of A 342 was significantly increased in the brain slices of STZ / HFD diabetic mice, while the $A \beta 42$ staining reduced after treatment of diabetic mice with telmisartan.

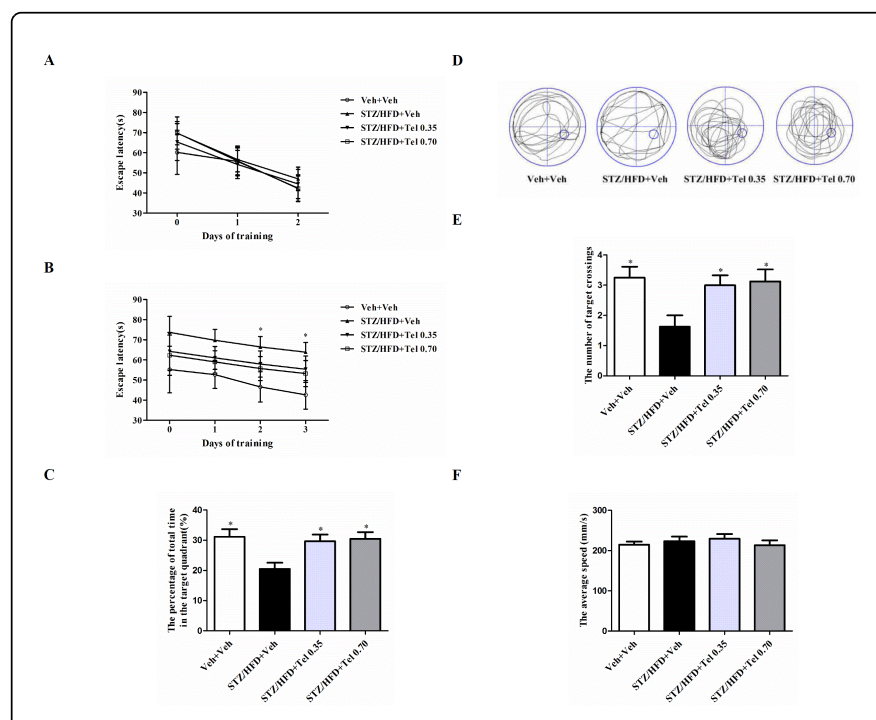

Figure 1: Effects of telmisartan on cognitive impairment in STZ / HFD diabetic mice. Memory function was assessed by the MWM test. The day 0 represent performance on the first trial and subsequent points indicate average of all daily trials. (A) No differences in the escape latency among all groups during the 2 day visible platform test. (B) The escape latency of mice in the hidden platform during the 3 day acquisition trials was presented. (C) The percentage of time spent in the target quadrant during the probe trial test and (D) representative swim paths of mice in each group during the probe trial test. (E) The average number of times of crossing the platform. (F) The average swimming speed of locomotive parameter. All values are expressed as mean \pm SEM; $n=$ 10. ${ }^{*} \mathrm{p}<0.05$ versus untreated STZ / HFD -induced diabetic group. 
Citation: Tao DG, Dong RR, Wang C, Guang JL, Tang SS (2016) Telmisartan Improves Memory Impairment in a Mouse Model of Type 2

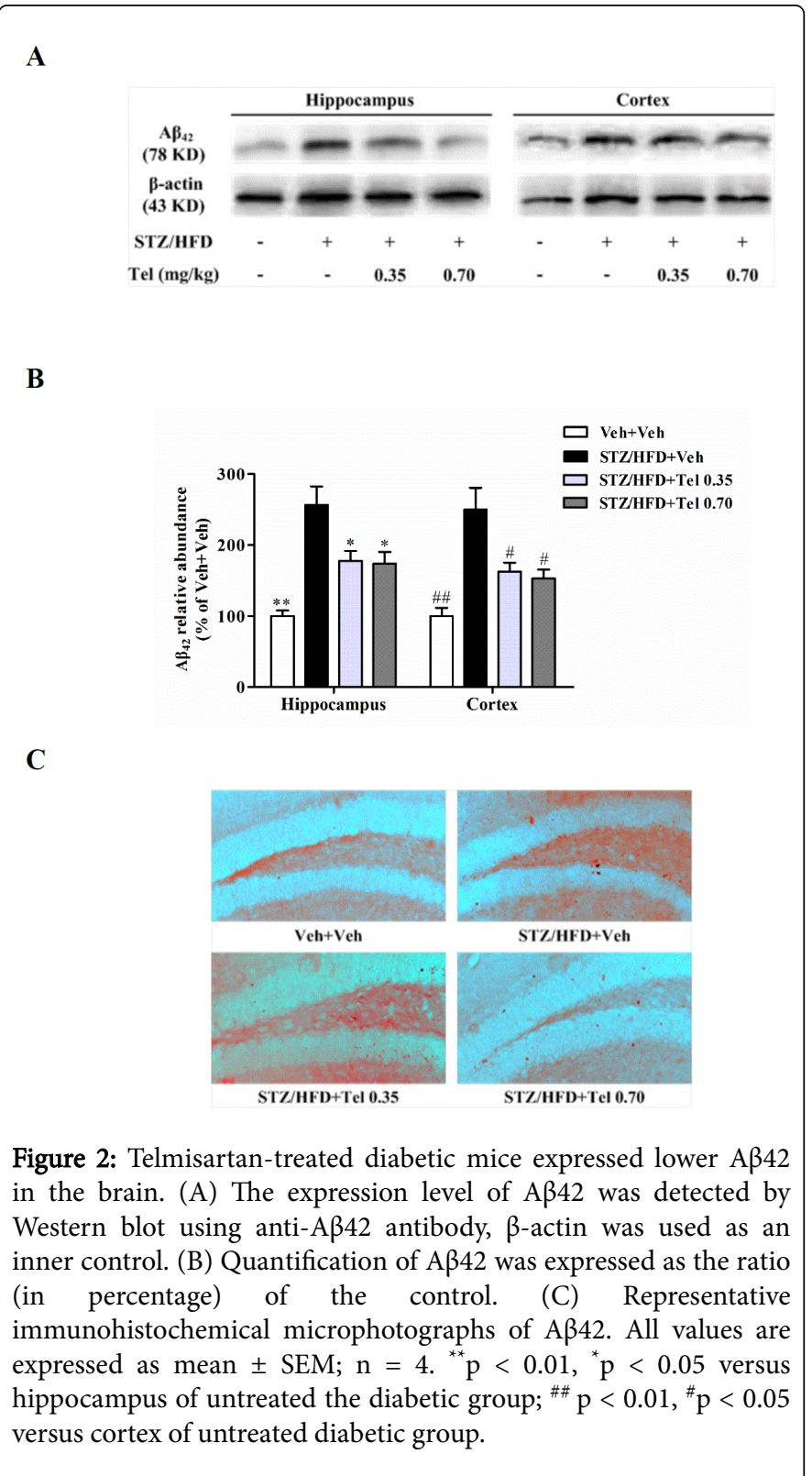

\section{Treatment with telmisartan lowers brain APP and BACE1 in} the diabetic mice

APP, an amyloid- $\beta$-protein precursor, is cleaved by a transmembrane aspartic proteinase BACE1 to produce souble sAPP $\beta$ and C99 fractions [28], which is closely related with $A \beta 42$ generation. APP levels were significantly increased to $237 \%$ and $241 \%$ in the hippocampus and cortex of STZ / HFD-induced diabetic mice, compared with control mice. Treatment with telmisartan significantly decreased APP expression in the brain of diabetic mice (hippocampus: $\mathrm{F}(3,15)=13.298, \mathrm{P}<0.05$; cortex: $\mathrm{F}(3,15)=12.994, \mathrm{P}<0.05$, Figures $3 \mathrm{~A}$ and $3 \mathrm{~B})$. We next observed the effect of telmisartan on cerebral BACE1 in the STZ / HFD-induced diabetic mice. BACE1 levels of hippocampus and cortex in diabetic mice significantly increased $135 \%$ and $159 \%$ compared with control mice, whereas chronic treatment with telmisartan at $0.35 \mathrm{mg} / \mathrm{kg}$ or $0.70 \mathrm{mg} / \mathrm{kg}$ led to a significant decrease of BACE1 levels in the hippocampus $(\mathrm{F}(3,15)=13.575, \mathrm{P}<$ 0.05 , Figures $3 \mathrm{~A}$ and $3 \mathrm{C}]$ and cortex $(\mathrm{F}(3,15)=12.302, \mathrm{P}<0.05$, Figures $3 \mathrm{~A}$ and $3 \mathrm{C}$ ) of diabetic mice.

A

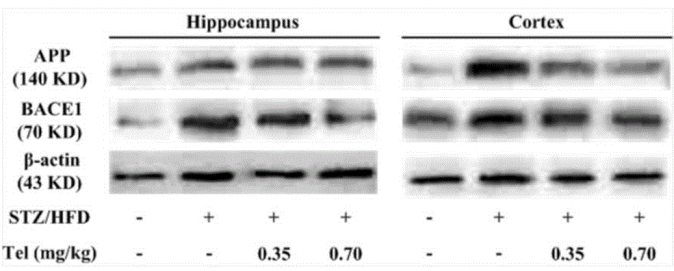

B

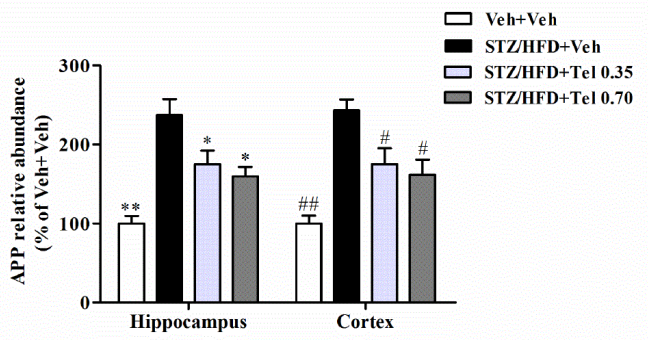

C

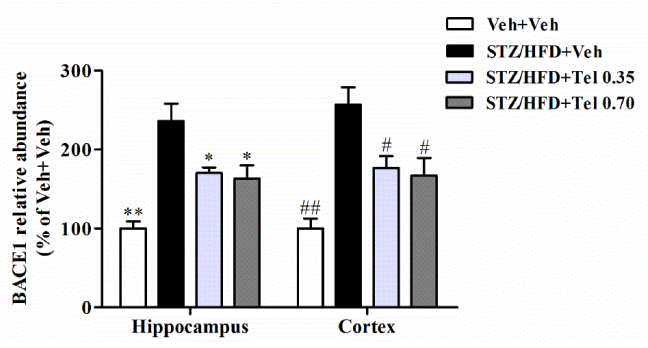

Figure 3: Telmisartan treatment reduced APP and BACE1 in hippocampus and cerebral cortex in STZ / HFD-induced diabetic mice. (A) Representative immunoblots APP and BACE1 was determined by Western blot using respective antibodies, $\beta$-actin was used as an inner control. (B) Quantification of APP and BACE1 was expressed as the ratio (in percentage) of the control. All values are expressed as mean \pm SEM; $\mathrm{n}=4 .{ }^{* *} \mathrm{p}<0.01,{ }^{*} \mathrm{p}<0.05$ versus hippocampus of untreated the diabetic group; ${ }^{\# \#} \mathrm{p}<0.01,{ }^{\#} \mathrm{p}<0.05$ versus cortex of untreated diabetic group.

\section{Telmisartan treatment reduced brain RAGE and NF-kB in STZ / HFD-induced diabetic mice}

Previous studies showed that RAGE is involved in $A \beta$-mediated memory deficits in the T2D [25]. Our results here showed that RAGE levels markedly elevated (132\% and 148\%) in the hippocampus and cortex in STZ / HFD-induced diabetic mice, compared with control mice. Telmisartan at the dose of $0.35 \mathrm{mg} / \mathrm{kg}$ or $0.70 \mathrm{mg} / \mathrm{kg}$ inhibited the increase of RAGE levels in both the hippocampus $(\mathrm{F}(3,15)=$ $12.560, \mathrm{P}<0.05$, Figures $4 \mathrm{~A}$ and $4 \mathrm{~B})$ and cortex $(\mathrm{F}(3,15)=12.648, \mathrm{P}<$ 0.05 , Figures $4 \mathrm{~A}$ and $4 \mathrm{~B})$. Current evidence suggests that NF- $\kappa \mathrm{B}$ signaling is closely associated with $A \beta 42$ production $[2,29,30]$. Thus, we detected nuclear NF- $\kappa$ B p 65 by Western blot since NF- $\kappa$ B signaling is characterized by a p65 subunit increment in the nucleus. The nuclear 
Page 5 of 7

NF- $\mathrm{BB}$ p 65 showed $166 \%$ and $181 \%$ increase in both the hippocampus and cortex in the diabetic mice compared with control mice. Telmisartan treatment significantly decreased nuclear NF- $\kappa B$ p65 in both the hippocampus $(\mathrm{F}(3,15)=12.533, \mathrm{P}<0.05$, Figures $4 \mathrm{C}$ and $4 \mathrm{D})$ and cortex $(\mathrm{F}(3,15)=15.464, \mathrm{P}<0.05$, Figures $4 \mathrm{C}$ and $4 \mathrm{D})$.

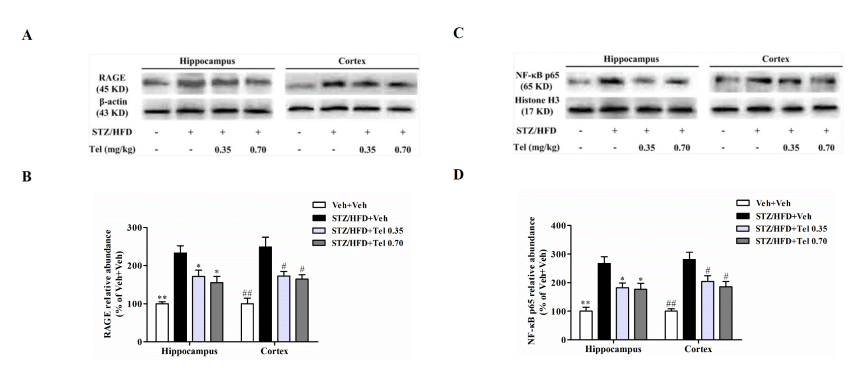

Figure 4: Telmisartan reversed elevation of NF- $\kappa \mathrm{B}$ p65 and RAGE in hippocampus and cerebral cortex in STZ / HFD-induced diabetic mice. (A and B) Representative immunoblots of RAGE and NF- $\kappa B$ p65 and was determined by Western blot using respective antibodies, $\beta$-actin and histone $\mathrm{H} 3$ was used as an inner control. (C and D) Quantification of RAGE and NF- $\mathrm{kB}$ was expressed as the proportion (in percentage) of the control. All values are expressed as mean \pm SEM; $\mathrm{n}=4 .{ }^{* *} \mathrm{p}<0.01,{ }^{*} \mathrm{p}<0.05$ versus hippocampus of untreated the diabetic group; ${ }^{\# \#} \mathrm{p}<0.01,{ }^{\#} \mathrm{p}<0.05$ versus cortex of untreated diabetic group.

\section{Telmisartan treatment has no effects on body weight, blood glucose, and insulin in the diabetic mice}

After 5 week treatment with telmisartan, no significant differences were observed in body weight among the diabetic mice of each group.
Telmisartan at $0.35 \mathrm{mg} / \mathrm{kg}$ or $0.70 \mathrm{mg} / \mathrm{kg}$ didn't improve blood glucose and serum insulin in the STZ / HFD-induced diabetic mice $(\mathrm{P}>0.05$, Table 1).

\section{Discussion}

STZ / HFD-induced diabetic animal model, one of the most frequently used models of $\mathrm{T} 2 \mathrm{D}$, is characterized by hyperglycemia, hyperlipemia and hypoinsulinemia, and is associated with impaired hippocampus-dependent learning and memory [2,31]. Interestingly, animal models of T2D exhibited Alzheimer-like changes, such as accumulation of APP and $A \beta[2,32,33]$. Thus, $A \beta$ accumulation in the brain is one of the reasons for diabetes-associated cognitive impairment. It is well known that $A \beta$ is a cleavage product derived from APP followed by a sequential cleavage by a BACE1 ( $\beta$-secretase) and $\gamma$-secretase. APP is processed to generate various peptide species, including the potential toxic form $\mathrm{A} \beta 42$ that is prone to oligomerization, leading to neurotoxicity [34]. In the present study, ICR mice were fed with HFD for 4 weeks and then injected with a single low dose of STZ followed by continued HFD feeding for an additional 4 weeks to generate a nongenetic rodent model mimicking human T2D, which displayed significant cognitive impairment evidenced by decreases in number of times of crossing the platform and percentage of time spent in the target quadrant in the MWM test, coupled with the elevated APP and A $\beta 42$ in brain. Chronic treatment with telmisartan significantly ameliorated memory deficits and decreased APP and A $\beta 42$ in the hippocampus and cortex. Telmisartan treatment also reduced BACE1, RAGE, and nuclear NF- $\kappa \mathrm{B}$ p65 in the brain, but did not attenuate hyperglycemia or hypoinsulinemia in STZ / HFD -induced diabetic mice.

\begin{tabular}{|l|l|l|l|l|l|}
\hline Groups & $\begin{array}{l}\text { Intial body weight } \\
\text { (g) }\end{array}$ & $\begin{array}{l}\text { Final body } \\
\text { weight (g) }\end{array}$ & $\begin{array}{l}\text { Intial blood glucose } \\
\text { (mmol/L) }\end{array}$ & $\begin{array}{l}\text { Final blood glucose } \\
\text { (mmol/L) }\end{array}$ & $\begin{array}{l}\text { Final serum insulin } \\
\text { (ng/ml) }\end{array}$ \\
\hline Veh + Veh & $31.8 \pm 1.24$ & $35.77 \pm 1.39$ & $4.92 \pm 0.12$ & $5.64 \pm 0.07$ & $0.77 \pm 0.22$ \\
\hline STZ / HFD + Veh & $35.50 \pm 1.14$ & $32.40 \pm 1.23$ & $13.45 \pm 1.44$ & $14.56 \pm 1.06$ & $0.35 \pm 0.06$ \\
\hline STZ / HFD + Tel (0.35 mg/kg) & $35.41 \pm 1.19$ & $34.00 \pm 1.19$ & $13.65 \pm 1.35$ & $15.15 \pm 0.61$ & $0.36 \pm 0.07$ \\
\hline STZ / HFD + Tel (0.70 mg/kg) & $35.67 \pm 1.49$ & $33.10 \pm 1.16$ & $13.80 \pm 1.42$ & $15.10 \pm 0.73$ & $0.31 \pm 0.04$ \\
\hline
\end{tabular}

Table 1: No effects of telmisartan on body weight, blood glucose, and insulin in STZ/HFD-induced diabetic mice. All values are expressed as the mean \pm SEM $(\mathrm{n}=8-10) .{ }^{* *} \mathrm{P}<0.01$ versus untreated STZ / HFD -induced diabetic group.

Chronic hyperglycemia, a characteristic feature of diabetes, contributes to the generation of advanced glycation end products (AGEs), senescent protein derivatives that result from the autooxidation of glucose and fructose [35]. Binding of AGEs to RAGE stimulates intracellular signaling, such as NF- $\mathrm{kB}$, and subsequently regulates expression of some genes. The accumulation of AGEs has been known to progress at an accelerated rate in diabetes, which play a key role in diabetic complications [36,37]. Some studies showed that both APP and BACE1 promoter contain a binding site for NF- $\mathrm{KB}$ p65 $[38,39]$ and expression of both APP and BACE1 was markedly increased in diabetic animals $[2,29,40]$. Thus, it is strongly suggested that stimulation of the AGEs / RAGE axis, as a result of hyperglycemia, might initiate intracellular NF- $\kappa B$ signaling and lead to increases of
APP and A $\beta$ in diabetic animals. In addition, the increased AGEs or A $\beta$ continued binding RAGE, which, in turn, enhanced NF- $\kappa B$ signaling, thereby triggering a positive feedback loop [37]. As expected, enhancement of the NF- $\kappa \mathrm{B}$ signaling, which is characterized by elevated nuclear NF- $\kappa$ B p65, and increased APP, BACE1, and RAGE were observed in STZ / HFD-induced diabetic mice. The reninangiotensin system (RAS) contributes to the development and progression of diabetic encephalopathy too [41]. Importantly, there exists the cross-talk between the RAS and the AGE-RAGE system [42]. It was shown that AT1R signaling contributes to diabetes-induced neuro-inflammation such as increases of angiotensin II and intercellular adhesion molecule-1 (ICAM-1), leukocyte adhesion, etc. [41,43]. Angiotensin II functions as a pro-inflammatory factor to 
trigger NF- $\kappa \mathrm{B}$ signaling and RAGE expression $[42,44]$. Angiotensin II is a final product of the RAS produced from angiotensinogen through enzymatic cascade reactions, and the RAS components required for the generation of angiotensin II are reported to exist in the brain [45-47]. Binding of angiotensin II to AT1R mediates pro-inflammatory molecule production and free radical generation that contribute to tissue damage, and blocking angiotensin II signaling protects against neurodegenerative processes [47]. Telmisartan can penetrate the blood-brain barrier (BBB) since it has higher lipophilicity [19]. Some study showed that telmisartan shows neuroprotective effects, and improves AD-related memory impairments [19,48,49], and these actions of telmisartan are attributed to its potential anti-oxidative [8], anti-inflammatory [9], and anti-A $\beta$ effects [19]. In this study, telmisartan at either $0.70 \mathrm{mg} / \mathrm{kg}$ or $0.35 \mathrm{mg} / \mathrm{kg}$ did not produce a hypotensive effect confirmed by blood pressure recording [19]. A nonhypotensive dose of telmisartan preferred to block binding of Angiotensin II to cerebral AT1R because of the higher distribution of this receptor in the brain, resulting in a suppression of $N F-\kappa B$ signaling. Additionally, telmisartan is a unique ARB with a partial peroxisome proliferator-activated receptor-gamma $(\operatorname{PPAR} \gamma)$ agonistic property [50-52], and PPAR $\gamma$ can block NF - $\kappa B$-dependent gene expression through co-repressor interference [53]. Thus, it is strongly indicated that the underlying mechanism of telmisartan decreasing expression of APP, BACE1, and RAGE through suppression of NF- $\kappa B$ signaling in the brains of diabetic mice. However, one limitation of our study is that the results would not explain whether telmisartan improved cognitive impairment by reducing angiotensin II activationinduced calcium oscillation, which is closely related with cognitive deficits $[53,54]$.

Overall, our study demonstrated that chronic administration of telmisartan improves learning and memory deficits in STZ / HFDinduced diabetic mice. This effect is probably associated with alleviation of amyloidosis in the brain rather than attenuation of hyperglycemia and hypoinsulinemia in the periphery. Our study has important implications for patients with T2D, suggesting a potential role for telmisartan as an adjuvant therapy for the prevention and treatment of diabetes-associated memory impairment.

\section{Acknowledgement}

This work was supported, in part, by grants from the National Natural Science Foundation of China (81273497).

\section{References}

1. Morley JE (2008) Diabetes and aging: epidemiologic overview. Clin Geriatr 24: 395-405.

2. Jiang LY, Tang SS, Wang XY, Liu LP, Long Y, et al. (2012) PPAR agonist pioglitazone reverses memory impairment and biochemical changes in a mouse model of type 2 diabetes mellitus. CNS Neurosci Ther 18: 659-666.

3. Verdile G, Fuller SJ, Martins RN (2015) The role of type 2 diabetes in neurodegeneration. Neurobiol Dis 84: 22-38.

4. Biessels GJ, Reijmer, YD (2014) Brain changes underlying cognitive dysfunction in diabetes: what can we learn from MRI? Diabetes 63: 2244-2252.

5. Duarte JMN (2015) Metabolic Alterations Associated to Brain Dysfunction in Diabetes. Aging Dis 6: 304-321.

6. Hajjar I, Rodgers K (2013) Do angiotensin receptor blockers prevent Alzheimer s disease? Curr Opin Cardiol 28: 417-425.

7. Kurinami H, Shimamura M, Sato N, Nakagami H, Morishita R (2013) Do angiotensin receptor blockers protect against Alzheimer's disease? Drugs Aging 30: 367-372.
8. Jung KH, Chu K, Lee ST, Kim SJ, Song EC, et al. (2007) Blockade of AT1 receptor reduces apoptosis, inflammation, and oxidative stress in normotensive rats with intracerebral hemorrhage. J Pharmacol Exp Ther 322: 1051-1058.

9. Kasahara Y, Taguchi A, Uno H, Nakano A, Nakagomi T, et al. (2010) Telmisartan suppresses cerebral injury in a murine model of transient focal ischemia. Brain Res 1340: 70-80.

10. Wincewicz D, Braszko JJ (2014) Telmisartan attenuates cognitive impairment caused by chronic stress in rats. Pharmacol Reports 66 : 436-441.

11. Wincewicz D, Braszko JJ (2015) Angiotensin II AT1 receptor blockade by telmisartan reduces impairment of spatial maze performance induced by both acute and chronic stress. J Renin Angiotensin Aldosterone Syst 16: 495-505.

12. Garrido GP, Joglar B, Rodriguez PAI, Guerra MJ, Labandeira GJL (2012) Involvement of PPAR in the neuroprotective and anti-inflammatory effects of angiotensin type 1 receptor inhibition: effects of the receptor antagonist telmisartan and receptor deletion in a mouse MPTP model of Parkinson s disease. J Neuroinflammation 9: 38.

13. Kishi T, Hirooka Y, Sunagawa K (2012) Telmisartan protects against cognitive decline via up-regulation of brain-derived neurotrophic factor / tropomyosin-related kinase B in hippocampus of hypertensive rats. J Cardiol 60: 489-494.

14. Kurata T, Lukic V, Kozuki M, Wada D, Miyazaki K, et al. (2015) Longterm Effect of Telmisartan on Alzheimers Amyloid Genesis in SHR-SR After tMCAO. Transl Stroke Res 6: 107-115.

15. Sharma B, Singh N (2012) Experimental hypertension induced vascular dementia:pharmacological, biochemical and behavioral recuperation by angiotens in receptor blocker and acetylcholinesterase inhibitor. Pharmacol Biochem Behav 102: 101-108.

16. Mogi M, Li JM, Tsukuda K, Iwanami J, Min LJ, et al. (2008) Telmisartan prevented cognitive decline partly due to PPAR-gamma activation. Biochem Biophys Res Commun 375: 446-449.

17. Shindo T, Takasaki K, Uchida K, Onimura R, Kubota K, et al. (2012) Ameliorative effects of telmisartan on the inflammatory response and impaired spatial memory in a rat model of Alzheimer's disease incorporating additional cerebrovascular disease factors. Biol Pharm Bull 35: 2141-2147.

18. Singh B, Sharma B, Jaggi AS, Singh N (2013) Attenuating effect of lisinopril and telmisartan in intracerebroventricular streptozotocin induced experimental dementia of Alzheimers disease type: possible involvement of PPAR-g agonistic property. J Renin Angiotensin Aldosterone Syst 14: 124-136.

19. Tsukuda K, Mogi M, Iwanami J, Min LJ, Sakata A, et al. (2009) Cognitive deficit in amyloid-beta-injected mice was improved by pretreatment with a low dose of telmisartan partly because of peroxisome proliferatoractivated receptor-gamma activation. Hypertension 54: 782-787.

20. Gore PN, Badar VA, Hardas MM, Bansode VJ, Navale SB (2014) Comparative effects of telmisartan and lisinopril on cognitive function in metabolic syndrome patients. Inter J Clin Exp Physiol 1: 3.

21. Li W, Zhang JW, Lu F, Ma, MM, Wang JQ et al. (2012) Effects of telmisartan on the level of A1-42, interleukin-1, tumor necrosis factor \pm and cognition in hypertensive patients with Alzheimer's disease. Zhonghua yi xue za zhi 92: 2743-2746.

22. Du GT, Hu M, Mei ZL, Wang C, Liu G, et al. (2014) Telmisartan treatment ameliorates memory deficits in streptozotocin-induced diabetic mice via attenuating cerebral amyloidosis. J pharmacol sci 124: 418-426.

23. Zhou J, Xu G, Yan J, Li K, Bai Z, et al. (2015) Rehmannia glutinosa (Gaertn.) DC. polysaccharide ameliorates hyperglycemia, hyperlipemia and vascular inflammation in streptozotocin-induced diabetic mice. Journal of ethnopharmacology 164: 229-238.

24. Ding L, Qu Z, Chi J, Shi R, Wang L, et al. (2015) Effects of preventative application of metformin on bile acid metabolism in high fat-fed / streptozotocin-diabetic rats. International journal of clinical and experimental pathology 8: 5450-5460. 
Citation: Tao DG, Dong RR, Wang C, Guang JL, Tang SS (2016) Telmisartan Improves Memory Impairment in a Mouse Model of Type 2 Diabetes. Clin Exp Pharmacol 6: 204. doi:10.4172/2161-1459.1000204

Page 7 of 7

25. Liu Z, Chen H, Wu PPF, Yao Q, Yu W, et al. (2015) Flos Puerariae Extract Ameliorates Cognitive Impairment in Streptozotocin-Induced Diabetic Mice. Evidence-Based Complementary and Alternative Medicine 2015.

26. Wang H, Chen F, Zhong KL, Tang SS, Hu M, et al. (2015) PPAR agonists regulate bidirectional transport of amyloid across the blood-brain barrier and hippocampus plasticity in $\mathrm{db} / \mathrm{db}$ mice. Br J Pharmacol

27. Chen F, Dong RR, Zhong KL, Ghosh A, Tang SS, et al. (2015) Antidiabetic drugs restore abnormal transport of amyloid across the blood-brain barrier and memory impairment in $\mathrm{db} / \mathrm{db}$ mice. Neuropharmacology 101: 123-136.

28. Joanna M (2003) Exclusively targeting secretase to lipid rafts by GPIanchor addition up-regulates site processing of the amyloid precursor protein. Proc Natl Acad Sci U S A 100: 11735-11740.

29. Liu LP, Yan TH, Jiang LY, Hu W, Hu M, et al. (2013) Pioglitazone ameliorates memory deficits in streptozotocin-induced diabetic mice by reducing brain amyloid through PPAR activation. Acta Pharmacol Sin 34: 455-463.

30. Tang SS, Hong H, Chen L, Mei ZL, Ji MJ, et al. (2014) Involvement of cysteinyl leukotriene receptor 1 in A 1-42-induced neurotoxicity in vitro and in vivo. Neurobiol Aging 35: 590-599.

31. Kodl CT, Seaquist ER (2008) Cognitive dysfunction and diabetes mellitus. Endocr Rev 29: 494-511.

32. Li ZG, Zhang W, Sima AA (2007) Alzheimer-like changes in rat models of spontaneous diabetes. Diabetes 56: 1817-1824.

33. Sato N, Morishita R (2014) Brain alterations and clinical symptoms of dementia in diabetes: tau-dependent and independent mechanisms. Front Endocrinol (Lausanne). 5: 143.

34. De Strooper B, Annaert W (2000) Proteolytic processing and cell biological functions of the amyloid precursor protein. J Cell Sci 113: 1857-1870.

35. Bucala R, Cerami A (1992) Advanced glycosylation: chemistry, biology, and implications for diabetes and aging. Adv Pharmacol 23: 1-34.

36. Thorpe SR, Baynes JW (2003) Maillard reaction products in tissue proteins: new products and new perspectives. Amino Acids 25: 275-281.

37. Yamagishi S, Matsui T, Nakamura K (2007) Kinetics, role and therapeutic implications of endogenous soluble form of receptor for advanced glycation end products (sRAGE) in diabetes. Curr Drug Targets 8: 1138-1143.

38. Bourne KZ, Ferrari DC, Lange DC, Rossner S, Wood TG, et al. (2007) Differential regulation of BACE1 promoter activity by nuclear factor-B in neurons and glia upon exposure to beta-amyloid peptides. J Neurosci Res 85: 1194-1204.

39. Chami L, Buggia PV, Duplan E, Delprete D, Chami M, et al. (2012) Nuclear factor B regulates APP and secretases differently at physiological and supraphysiological A concentrations. J Biol Chem 287: 24573-24584.

40. Jung SW, Han OK, Kim SJ (2010) Increased expression of $\beta$ amyloid precursor gene in the hippocampus of streptozotocin-induced diabetic mice with memory deficit and anxiety induction. J Neural Transm 117: 1411-1418.
41. Vargas R, Rincón J, Pedreañez A, Viera N, Hernández FJP, et al. (2012) Role of angiotensin II in the brain inflammatory events during experimental diabetes in rats. Brain Res 1453: 64-76.

42. Nakamura K, Yamagishi S, Nakamura Y, Takenaka K, Matsui T, et al. (2005) Telmisartan inhibits expression of a receptor for advanced glycation end products (RAGE) in angiotensin-II-exposed endothelial cells and decreases serum levels of soluble RAGE in patients with essential hypertension. Microvasc Res 70: 137-141.

43. Kurihara T, Ozawa Y, Nagai N, Shinoda K, Noda K, et al. (2008) Angiotensin II type 1 receptor signaling contributes to synaptophysin degradation and neuronal dysfunction in the diabetic retina. Diabetes 57:2191-2198.

44. Nagai N, Izumi NK, Oike Y, Koto T, Satofuka S, et al. (2007) Suppression of diabetes-induced retinal inflammation by blocking the angiotensin II type 1 receptor or its downstream nuclear factor- $\mathrm{kB}$ pathway. Invest Ophthalmol Vis Sci 48: 4342-4350.

45. Saavedra JM (2012) Angiotensin II AT(1) receptor blockers ameliorate inflammatory stress: a beneficial effect for the treatment of brain disorders. Cell Mol Neurobiol 32: 667-681.

46. Wright JW, Harding JW (2011) Brain reninangiotensin a new look at an old system. Prog. Neurobiol 95: 49-67.

47. Benigni A, Cassis P, Remuzzi G (2010) Angiotensin II revisited: new roles in inflammation, immunology and aging. EMBO Mol Med 2: 247-257.

48. Kurihara T, Ozawa Y, Shinoda K, Nagai N, Inoue M, et al. (2006) Neuroprotective effects of angiotensin II type 1 receptor (AT1R) blocker, telmisartan, via modulating $\mathrm{AT} 1 \mathrm{R}$ and $\mathrm{AT} 2 \mathrm{R}$ signaling in retinal inflammation. Invest Ophthalmol Vis Sci 47: 5545-5552.

49. Kobayashi T, Kawamata T, Shibata N, Okada Y, Kobayashi M, et al. (2009) Angiotensin II type 1 receptor blocker telmisartan reduces cerebral infarct volume and peri-infarct cytosolic phospholipase $\mathrm{A}(2)$ level in experimental stroke. J Neurotrauma 26: 2355-2364.

50. Balaji SP, Chand CV, Justin A, Ramanathan M (2015) Telmisartan mediates anti-inflammatory and not cognitive function through PPAR- $\gamma$ agonism via SARM and MyD88 signaling. Pharmacol Biochem Behav 137: 60-68.

51. Biessels GJ, Reijmer YD (2014) Brain changes underlying cognitive dysfunction in diabetes: what can we learn from MRI? Diabetes 63: 2244-2252.

52. Wang J, Pang T, Hafko R, Benicky J, Sanchez LE, et al. (2014) Telmisartan ameliorates glutamate-induced neurotoxicity: Roles of AT1 receptor blockade and PPARg activation. Neuropharmacology 79: 249-261.

53. Pascual G, Fong AL, Ogawa S, Gamliel A, Li AC, et al. (2005) A SUMOylation-dependent pathway mediates trans-repression of inflammatory response genes by PPAR-gamma. Nature 437: 759-763.

54. Edwards A, Pallone TL (2008) Mechanisms underlying angiotensin IIinduced calcium oscillations. Am Journal Physiol Renal Physiol 295: F568-F584. Santulli GR, Marks A (2015) Essential roles of intracellular calcium release channels in muscle, brain, metabolism, and aging. Curr mol pharmacol 8: 206-222. 